\title{
DISTRIBUTION OF AGRICULTURAL LANDS AND LAND OWNERSHIP IN RUSSIA
}

\author{
Ivan Ryazantsev ${ }^{1}$, Anna Ivolga ${ }^{2}$ \\ *Corresponding author_E-mail: annya_iv@mail.ru
}

\begin{abstract}
A R T I C LE IN F O
A B S T R A C T

Original Article

Among the countries of the world, Russia is one of the rich-

Received: 29 May 2021

est in agricultural land. However, a quantitative advantage is

Accepted: 17 November 2021

doi:10.5937/ekoPolj2104961R

UDC 332.145.22(470) poorly transformed into a qualitative one. As a result, there has been a gradual decrease in productive land, a decline in crop yields, the use of highly productive lands as less valuable land categories, and land degradation. These negative processes cause severe damage to both the agricultural sector

Keywords:

agricultural land, distribution, land fund, land tenure, land use, ownership, Russia

JEL: $Q 15, Q 24, R 14$ and the country's economy as a whole. One of the reasons for such drawbacks is the underdevelopment of land use processes and forms of land ownership, which discourage land productivity growth and rational use of agricultural lands. In this paper, the authors analyze the most critical challenges in the sphere of agricultural land distribution in Russia and suggest ways to improve the efficiency of land ownership and land use patterns.
\end{abstract}

(C) 2021 EA. All rights reserved.

\section{Introduction}

The contemporary agricultural sector in Russia operates in the conditions of aggravated external challenges due to the economic sanctions imposed by the USA and the EU, counter-sanctions on food imports set by Russia, and the need for import substitution of various categories of food and agricultural products (Erokhin \& Gao, 2020; Prabhakar et al., 2020). The solution to these problems is hardly possible without developing an efficient system of rational use of agricultural lands.

Russia's total area amounts to over 1.7 billion ha, excluding the internal and territorial sea (Federal Service for State Registration, Cadastre, and Cartography [Rosreestr], 2021). The land fund comprises wooded lands (65.8\% of the total land fund), agricultural lands $(22.4 \%)$, undistributed lands $(5.2 \%)$, lands of specially protected areas $(2.8 \%)$, residential areas $(1.2 \%)$, and industrial lands and other special-purpose lands (1.0\%).

1 Ivan Ryazantsev, Associate Professor, Stavropol State Agrarian University, 12, Zootekhnichesky Pereulok, Stavropol, 355017, Russia, Phone: +79887638358, E-mail: i-ryazancev@mail.ru, ORCID ID (https://orcid.org/0000-0003-3144-4301)

2 Anna Ivolga, Associate Professor, Stavropol State Agrarian University, 12, Zootekhnichesky Pereulok, Stavropol, 355017, Russia, Phone: +79280053542, E-mail: annya_iv@mail.ru, ORCID ID (https://orcid.org/0000-0001-5428-6090058) 
Farmland comprises 51.5\% (197.7 million ha) of the total agricultural land fund, while other types of agricultural land amount to $48.5 \%$ (186.0 million ha). Farmland is also a part of residential areas $(47.8 \%)$, lands under industrial and power facilities, transport, and communication infrastructure $(6.9 \%)$, lands of specially protected areas $(1.5 \%)$, wooded lands $(0.4 \%)$, and undistributed lands $(9.2 \%)$. The total farmland acreage amounts to 222.1 million ha or $13 \%$ of total Russia's land fund.

Despite these impressive figures, many scholars report poor conditions of many agricultural lands (Dugina, 2015; Gadzhiev, 2015; Kuzmich \& Gorr, 2016; Erokhin et al., 2020a; Panait et al. 2020; Constantin et al., 2021; Sikandar et al., 2021). Russia has failed to become a global food production leader with $10 \%$ of the world's agricultural land and $55 \%$ of black earth soils. Its modest share of the global gross agricultural production is about $1 \%$. The land transformations that have been evolving since the 1990s have not established explicitly favorable conditions for the rational use and protection of land (Dugina, 2015). The area of unused agricultural land is growing. It has reached $25 \%$ of their total area. Over the past fifteen years, the intended use has been changed for more than two million plots out of thirteen. Land degradation, water and wind erosion, desertification and waterlogging, thickening, and impoverishment of soils annually remove about two million ha of agricultural land from circulation. The agricultural output loss due to a decrease in land resource potential amounts to ten million tons of grain equivalent. Many agricultural organizations do not have rights to land. Therefore, land uses have not been legally individualized in particular territories as a unified land and property complex - an object of land and property legislation.

Most researchers agree that in the current conditions, new approaches to establishing national agricultural policy are required in Russia (Prishchepov et al., 2013; Gadzhiev, 2015; Erokhin et al., 2020b; Gao et al., 2019; Vorobyov et al., 2019; Khlystun, 2018; Kotelevskaya, 2018). However, the visions of such approaches vary. Thus, Trafimov and Nikonov (2018) and Kostyaev et al. (2015) emphasize the necessity to increase the concentration of agricultural lands in agricultural holdings that could improve access to land of small producers and provide incentives for revitalization and sustainable development of rural territories in Russia. Melnikov (2019) develops the concept of a multi-contour land plot as an object of land relations in respect to small and isolated areas and interspersed plots that cannot be effectively used separately from each other due to economic reasons. Zavorotin et al. (2019b) establish a methodological approach to studying the mechanism of land relations transformation in agriculture based on changing the institutional environment, analysis of institutions, costs, and factors, and identification and assessment of institutional traps. Zharov (2019) advocates for the comprehensive analysis of the land policy purpose along with the vector of contemporary development of the agricultural sector and the nature of land relations.

In view of diverse approaches to developing land policy measures, new methods are needed to ensure effective land use, high-quality accounting and evaluation, protection of land from degradation, and control over its intended use. Therefore, it is worthwhile drawing historical parallels between the current state of land policy and the experience 
of land relations reform, comparing methods of their regulation, assessing the risks of their application in current conditions, and selecting land policy tools that meet the contemporary needs of the agricultural sector and the entire economy. The authors hypothesize that a gradual decrease in the area of productive land and a decline in crop yields in Russia have emerged due to the underdevelopment of land use processes and forms of land ownership. In this light, the paper aims to analyze the most critical challenges in the sphere of agricultural land distribution in Russia and suggest ways to improve the efficiency of land ownership and land use patterns.

\section{Materials and methods}

This study involves the retrospective analysis of the land statistics database from the Federal Service for State Registration, Cadastre, and Cartography (Rosreestr). We analyzed land ownership and land distribution patterns in 2005-2020 to determine how the land market has evolved since the fundamental land reforms implemented in Russia in the 1990s - early 2000s. At stage 1, land ownership relations patterns were studied in terms of the transformation of ownership relations, privatization (diversification of land property forms into private, shared, and joint ownership), and demarcation of land ownership (federal, territorial, and municipal levels). At stage 2, we defined critical problems of contemporary land relations in Russia by studying the structure of agricultural land ownership (divided into the property of individuals, legal entities, and public property), agricultural land distribution by a form of management (agricultural organizations, peasant farm enterprises, individual entrepreneurs, private subsidiary farms and other households, and non-profit organizations), and the composition of agricultural land use by a form of ownership (agricultural organizations and peasant farm enterprises). Finally, at stage 3, we suggested measures to improve land distribution patterns and the efficacy of land relations in Russia.

\section{Results}

Russia's land reform in the early 1990s did not result in a fundamental change of land legislation. One of the examples is denationalization that established the foundations of private ownership of agricultural lands and allowed for the diversification of agricultural production. Carried out through privatization, denationalization translated into the following issues:

- In the early stage of the land reform, private ownership of agricultural land was not declared. Land plots were leased to farmers and rural dwellers for permanent use and lifetime heritable tenure.

- Preservation of state ownership of land plots for northern reindeer herding, crafts, Cossack societies, etc., building relations on land use of such land plots based on lease or various titles for use. 
- Preservation of state ownership of land plots used by certain types of agricultural enterprises (breeding, seed-growing, research, training, etc.);

- Lands were divided into four categories: land plots intended for free transfer to farm employees; land in state ownership transferred to municipal entities and rural settlements; mixed types of land that were allocated to regional entities for redistribution; non-agricultural land transferred to the successors of collective or state farms based on perpetual use right.

The establishment of private land ownership institutions involved paid and free approaches. The latter was implemented through the privatization of land shares according to the established regional rate. The free transfer was regulated at the regional level when the land was privatized by collective and state farms or transferred to private ones. To support the flexibility of the land reform, two mechanisms were introduced. First is the division of shared property and allocation of smaller plots. Thus, co-owners could allocate a land plot for starting a farm or making a transaction (lease, sale, contribution to the authorized capital, etc.). Second is the consolidation of land shares and allocation of land plots to prevent excessive fragmentation of agricultural lands.

The privatization allowed to establish land market and improve the flexibility of land ownership and land use. During state ownership transformation, part of agricultural land was privatized, which gave a grounding in private ownership and joint ownership. The latter was structured into shared and collective ownership. The remaining part of state ownership is undergoing a demarcation procedure (Figure 1). Land turnover made it possible for owners and people involved in agricultural production to conclude transactions and concentrate land shares.

Figure 1. Land ownership relations patterns in Russia as a result of the land reform

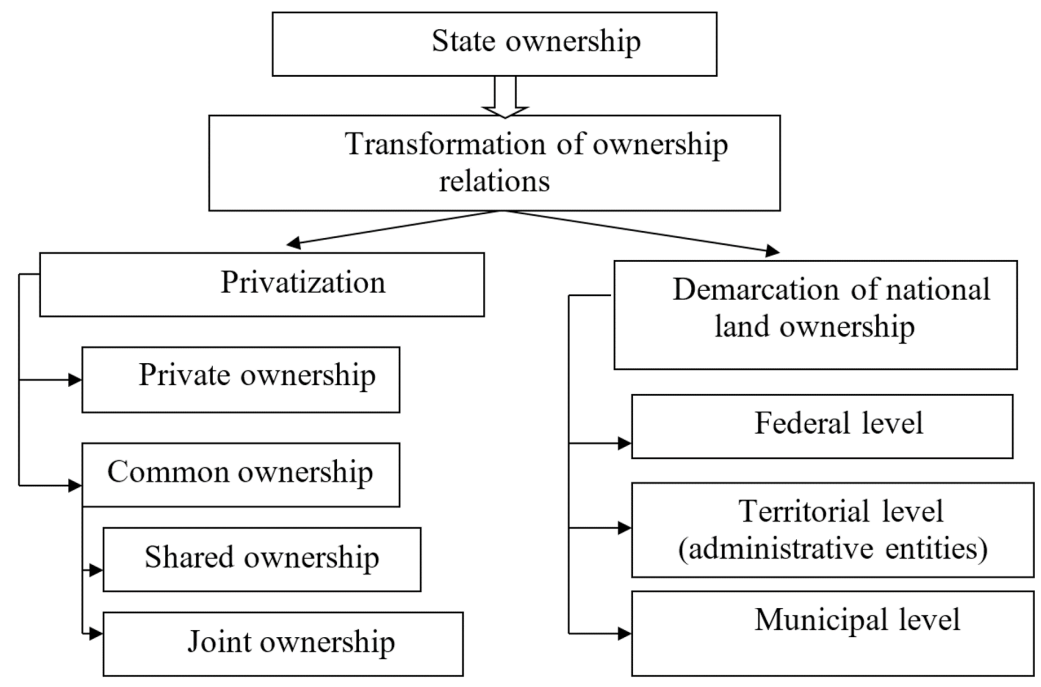

Source: Authors' development 
Nevertheless, the success of the reform has not eliminated problems in the field of land relations, the unresolved nature of which hinders the sustainable economic development of the agricultural sector today. Our analysis allowed us to define six core problems of contemporary land relations in Russia:

1. The lack of a clear land policy. No principles, content, or directions of land relations development have been comprehensively defined. There is no clear position on a number of important issues:

- should land privatization continue, or should the existing ownership structure be preserved, or should land be nationalized;

- whether the state intends to influence the design of land ownership, what it should look like in the future;

- how the state plans to build an effective system for regulating land relations and managing land resources;

- does the state intend to develop land market institutions, and what are its priorities in the field of land turnover;

The structure of land ownership is far from optimal (Table 1). About $67 \%$ of all agricultural land remains in state ownership. This portion has decreased by only $2 \%$ since the mid-2000s. State-owned lands are those where mismanagement, degradation, overgrowth, waterlogging, and other harmful processes occur the most.

Table 1. Structure of agricultural land ownership

\begin{tabular}{|l|r|r|r|r|r|}
\hline \multirow{2}{*}{ Ownership } & \multicolumn{2}{|c|}{2005} & \multicolumn{2}{c|}{2020} & \multirow{2}{*}{ Change, \% } \\
\cline { 2 - 5 } & million ha & \% of total & million ha & \% of total & \\
\hline Individuals & 120.7 & 30.1 & 106.6 & 27.9 & 88.3 \\
\hline Legal entities & 5.0 & 1.2 & 20.9 & 5.5 & 418.0 \\
\hline State (all levels) & 275.8 & 68.7 & 254.1 & 66.6 & 92.1 \\
\hline Total & 401.5 & 100.0 & 381.7 & 100.0 & 95.1 \\
\hline
\end{tabular}

Source: Authors' development based on Rosreestr (2021)

2. No significant changes to the structure of land distribution by a form of management. There is a tendency to reduce the land area of small businesses (Table 2), although the production volume in peasant farms has increased by almost $40 \%$ over the past decade.

Table 2. Agricultural land distribution by a form of management

\begin{tabular}{|l|r|r|r|r|r|}
\hline \multirow{2}{*}{ Ownership } & \multicolumn{2}{|c|}{2005} & \multicolumn{2}{|c|}{2020} & \multirow{2}{*}{ Change, \% } \\
\cline { 2 - 6 } & million ha & \% of total & million ha & \% of total & \\
\hline Agricultural organizations & 410.3 & 91.0 & 411.0 & 91.1 & 100.2 \\
\hline Peasant farm enterprises & 26.0 & 5.8 & 27.2 & 6.0 & 104.6 \\
\hline Individual entrepreneurs & 3.4 & 0.8 & 3.6 & 0.8 & 105.9 \\
\hline $\begin{array}{l}\text { Private subsidiary farms and } \\
\text { other households }\end{array}$ & 9.7 & 2.2 & 8.0 & 1.8 & 82.5 \\
\hline
\end{tabular}




\begin{tabular}{|l|r|r|r|r|r|}
\hline \multirow{2}{*}{ Ownership } & \multicolumn{2}{|c|}{2005} & \multicolumn{2}{|c|}{2020} & \multirow{2}{*}{ Change, \% } \\
\cline { 2 - 5 } & million ha & \% of total & million ha & $\%$ of total & \\
\hline Non-profit organizations & 1.2 & 0.3 & 1.6 & 0.3 & 133.3 \\
\hline Total & 450.6 & 100.0 & 451.4 & 100.0 & 100.2 \\
\hline
\end{tabular}

Source: Authors' development based on Rosreestr (2021)

Small farms produce about 30\% of grain, 11\% of sugar beet, and 30\% of sunflower, with their portion of the total land use of only 5.7\%. On the other hand, super-large landholdings continue to proliferate. Realizing the danger of over-concentration of land, developed countries strongly resist this process through anti-trust regulations and diversification policies. In Russia, on the contrary, the government provides the largest agricultural holdings with abundant subsidies.

3. Low share of own land in the use of agricultural organizations. The portion of land owned by agricultural organizations is only $3.8 \%$, while that of land leased from shared ownership and owned by the state is $53.5 \%$. Small businesses own $33.7 \%$ of their own land and use $64.2 \%$ of leased land (Figure 2).

Figure 2. Composition of agricultural land use by form of ownership, $\%$ of total land fund

a)

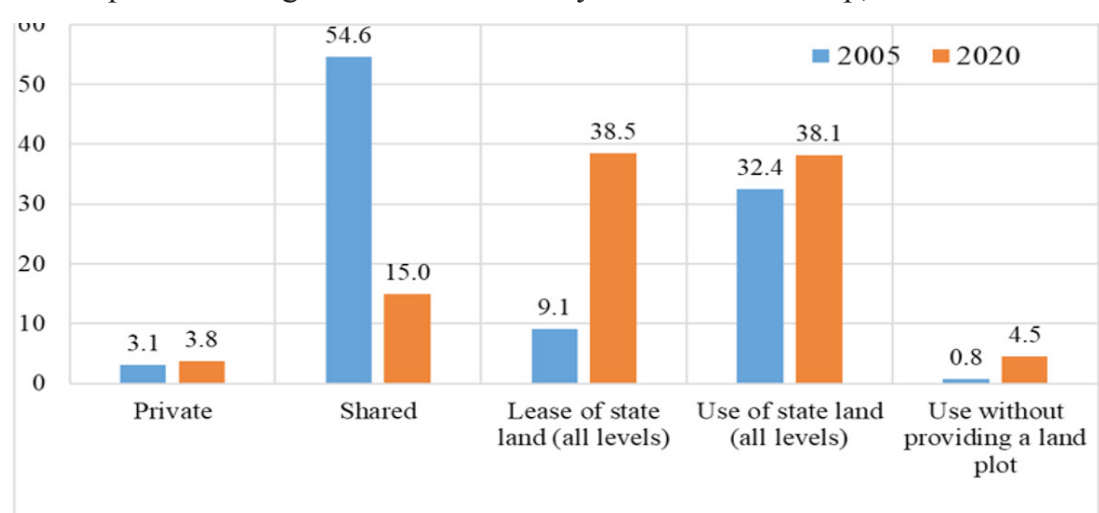

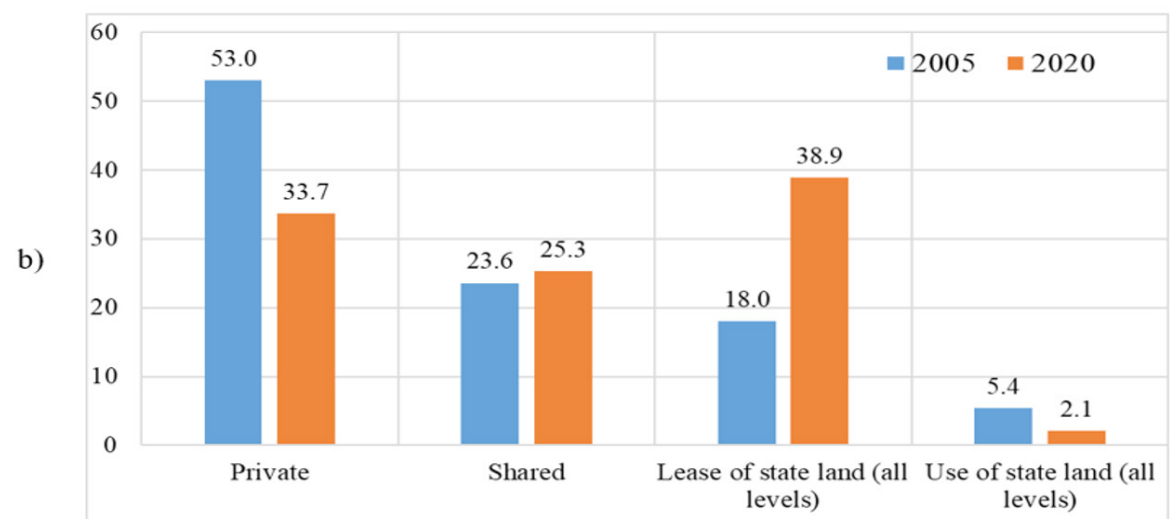

Note: a) agricultural organizations; b) peasant farm enterprises and individual entrepreneurs Source: Authors' development based on Rosreestr (2021) 
Khlystun (2019) reports that about $38 \%$ of the land is in the free use by organizations, while about $4.5 \%$ or 14.5 million ha is used illegally. Among small businesses, only $2.7 \%$ of the land is in legitimate use. The ratio of free land is $10: 1$, which indicates preferences of local authorities in the free provision of land to large businesses. Land shares were introduced as an institution for equalizing the distribution of agricultural land in their privatization. Initially, the land reform introduced a transition period for land shares (up to two years), during which they had to be transformed into either land plots or shares of the capital of corporate structures. However, they continue to exist, and they have become a significant obstacle to the further development of land ownership and land use since they cause uncertainty about land ownership.

4. Inadequate information on the quantity, structure, and dynamics of the land resources. During the transition period in the early 1990s, the destruction of the land cadastre systems, agricultural cartography, land management, land monitoring, and other information support tools for land management resulted in the lack of information for making management decisions on rational land use. Without establishing the exact boundaries of administrative entities, it is impossible to determine their legitimate jurisdiction to regulate land relations. The objectivity of information about land rights and the spatial characteristics of land plots should be reflected in the documents of the real estate cadastre. Without this, the legality of the use is questioned, which causes land use instability. The cadastre should provide accurate information about the availability, distribution, and condition of land plots.

5. Low efficacy of land management system. There is no single management body that would concentrate all functions, powers, and responsibilities for the organization of use and protection of the land fund in the country. Land regulation powers are divided among several ministries and agencies. The state control over land use and preservation is divided between four control bodies, whose activities are poorly coordinated. The division of powers has destroyed the unified land management system and resulted in a decrease in efficiency of land use forecasting and planning, remote sensing and monitoring, and cartographic support.

6. Acceleration of land degradation processes. The destruction of the institutions in the sphere of land study, land use planning, and land management has also led to the acceleration of water and wind erosion, desertification, salinization, waterlogging, and other negative phenomena. Khlystun (2019) estimates the annual increase in the gully plantings network to exceed twenty thousand $\mathrm{km}$. About half of the total area of arable land is subject to water erosion to varying degrees. According to Rosreestr (2021), water erosion affects $17.8 \%$ of the total area of agricultural land, wind erosion $-8.4 \%$, waterlogging $-12.3 \%$, and salinization $-20.1 \%$.

These findings indicate the need for a significant adjustment of the land policy. In our view, the following measures could be implemented:

- development and adoption of a fundamental document in the form of a state land policy doctrine; 
- formation of a land management system based on the re-establishment of a single body for regulation of land relations and organization of rational use and protection of agricultural land;

- re-establishment of institutions in such spheres of land use and protection of land resources as forecasting and planning, land management, land monitoring, and exploration and evaluation of land potential);

- carrying out a comprehensive inventory of agricultural land;

- establishment of an effective system to combat land degradation;

- anti-trust regulations to prevent concentration of land in mega-holdings (setting a limit on the size of the estates, lower support for extra-large estates, differential taxation);

- establishment of a system of information and consulting support for rational use and protection of agricultural land.

The above-defined measures can be integrated into a system of land management (Figure 3).

Figure 3. Measures of agricultural land management in Russia

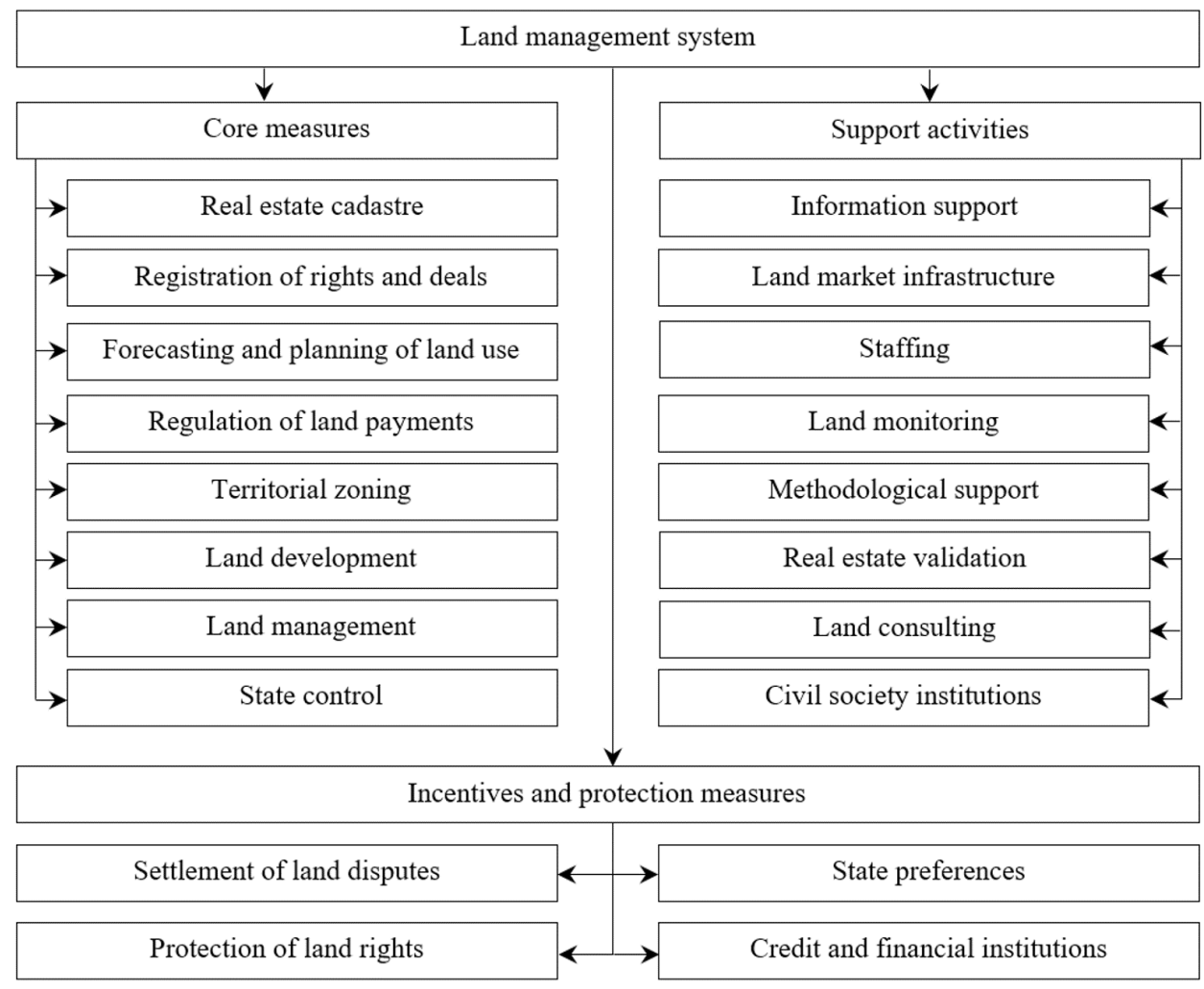

Source: Authors' development 
In our vision, such a system should include three blocks of measures: core measures, support activities, and incentives. The system is founded on the integration of institutions and tools that operate within a single concept. They are closely related to each other and work towards achieving common goals. Each block in the system should have methodological autonomy while respecting the established methodological approaches. A unique role in the proposed system belongs to land management as the primary tool for managing the processes of land redistribution, eliminating land use deficiencies, organizing agricultural production facilities, and developing programs and projects to prevent soil erosion and desertification.

\section{Discussions}

The results of our research allow us to define critical challenges to the development of agricultural land use, which are the irrational intersectoral redistribution of agricultural land, unregulated market turnover of agricultural land, and inefficient use of land in agricultural production. These findings well agree with many Russia-related studies in the sphere of land relations and land reform, including Dugina (2015), Mindrin and Leppke (2008), Kuzmich and Gorr (2016), Bryzhko (2013), Erokhin et al. (2020b), and Zavorotin et al. (2019a), among others. As a result, there has been a gradual decrease in productive land, a decline in crop yields, the use of highly fertile lands as less valuable land categories, and land degradation. These negative processes cause severe damage to both the agricultural sector and the country's economy as a whole. As demonstrated by Dugina (2015), Khlystun (2019), Saifidinov and Kostousova (2019), and Sergeeva (2019), the main reasons for the degradation of the land and resource potential in the agricultural sector are related to social, economic, and organizational factors. These include territorial uncertainty and instability of agricultural land users, underestimation of the role of agrotechnical, anti-erosion, and other measures in increasing land productivity, and unjustified land seizures for non-agriculture needs.

Internationally, land has been increasingly important as an object of management and economic activity rather than property. In the sphere of property rights, land legislation in Russia pursues outdated approaches, while in most of the developed countries, governments are increasingly taking on control functions in land markets (Dugina, 2015). According to many authors, including Scott et al. (2019), Kim (2019), Volkov et al. (2020), and Cai et al. (2020), the principle that the state restricts the rights of a landowner in favor of society or anyone who cultivates the land, is reasonable, since it relieves social tensions. Kuzmich and Gorr (2016) believe that the successful completion of land reform with the emergence of effective landowners is possible only due to the active position of the state, which provides for the use of available administrative and financial resources.

Diversifying land ownership and land tenure in establishing a sustainable land-use system is pivotal. A significant portion of agricultural output in Russia (primarily, in animal husbandry) is provided by private subsidiary households and small farms. However, it is problematic for a small farmer to establish its own distribution, processing, 
or at least storage of agricultural products. As a consequence, the added value is washed out of the agricultural complex and is redistributed in favor of intermediaries (processors or traders) (Minakov, 2017). The solution to this problem could be creating an infrastructure to promote the products of small farms jointly owned by producers themselves, i.e., agricultural cooperatives. Since 2005, the number of cooperatives in Russia has decreased by more than one-third, which can be explained by their low investment attractiveness. Investors are not interested in developing this form of agricultural production, while rural people have no funds of their own. Furthermore, most of the cooperatives work on leased land rather than on their own land, which also reduces the investment attractiveness. To develop cooperation as a condition for the full involvement of small farms in the effective land-use system, it is necessary to improve the methods and tools of state support to assist in creating cooperatives' material and technical capacities. The intensification of agriculture will improve the economic efficiency of agricultural cooperatives as alternative users of agricultural land.

Thus, it can be stated that the development of the agricultural sector in Russia should be supported by the elaboration of a strategy for improving the system of land relations through effective land use, public regulation and administration of the land market, and innovations. Our understanding is that land policy should clearly set goals, priorities, and tools for regulating land relations, the implementation of which will radically refocus the development on preserving and increasing the land potential. The primary goals of such policy could include:

- Completing the establishment of a system of land ownership and land use that fully ensures the implementation and protection of land rights of individuals, agricultural organizations, and public bodies to acquire and facilitate the rational use of land plots.

- Establishment of a civilized land market along with its infrastructure.

- Development of conditions and incentives for the rational and efficient use of land to meet the needs and interests of landholders, administrative entities, and the state.

- Protection of the country's land resources from degradation and mismanagement.

The perspective of the agricultural sector of the economy is closely linked to the decision on the future of land shares. The primary and necessary condition for the efficacy of agricultural land use is the stability of land rights. This principle ensures the development and strengthening of the interest in investing labor and money in land, a careful and economic attitude to land, and increasing soil fertility. The sustainability of a particular land use pattern is expressed in the long-term or permanent nature of land use. Currently, most of the agricultural land is formally owned by rural dwellers, and there is still no legal clarity on the allocation and use of these lands. The boundaries of land shares are not established even in the planning and cartographic documents. The main problem is the high cost of registration and the difficulty of making transactions. 
For the same reason, the number of unclaimed land shares is growing.

Different opinions about the formation of land use of agricultural organizations coexist in the economic literature. According to Mindrin and Leppke (2008), the economic mechanism of the transition of land shares should provide employees of agricultural enterprises with an opportunity to acquire them. The uncertainty of the legal situation entails the instability of land use, and, accordingly, agricultural production. It seems to us that the problem can be solved only by establishing long-term legal and industrial relations between agricultural enterprises and land share owners. This vision agrees with Kuzmich and Gorr (2016), who advocate mandatory public management and regulation of land redistribution and use. The priority measures to improve public management of agricultural lands should include:

- complete inventory of agricultural land and its cadastral registration;

- qualitative agrochemical survey of productive land necessary for assessing soil fertility and monitoring its reproduction;

- continuous monitoring of soil fertility and the development of measures to stimulate its reproduction;

- targeted use of agricultural land and encouraging the involvement of abandoned and uncultivated land in economic turnover;

- control over agricultural land turnover;

- ensuring transparency of transactions with land owned by the federal, regional, and municipal authorities;

- preventing purchases of agricultural land by foreign legal entities and individuals.

As demonstrated by Bryzhko (2013), Khlystun (2019), Kalugina (2019), Vishkaev and Musaev (2019), Vlasov et al. (2019), and Sharipov et al. (2018), among others, sustainable development of agricultural land use requires a comprehensive organizational and economic mechanism focused on improving the system of redistribution of land resources between industries, market turnover of agricultural land, the use of productive land in agriculture, and the practice of public management of agricultural lands. It is necessary to strengthen the priority of agricultural use of lands in order to sustain the territorial basis of agricultural production (Erokhin et al., 2020b). In particular, legal, administrative, and economic incentives for the rational use of land resources should be improved. Of great importance is the involvement of unused land in the turnover, a significant part of which is represented by unclaimed land shares as part of agricultural land (Gao et al., 2018).

\section{Conclusions}

The systematic and scientifically-based land policy is designated to create prerequisites for improving the efficiency of the use of productive land, increasing the volume of agricultural production, ensuring the food security of the country, and creating the 
potential for rural development. Implementing an adequate land policy involves a set of strategic directions that allow creating conditions for preserving agricultural land, involving them in economic turnover, and preventing land degradation and pollution.

In this study, the authors attempted to analyze the most critical challenges in the sphere of agricultural land distribution in Russia and suggest ways to improve the efficiency of land ownership and land use patterns. The land ownership relations patterns were studied regarding the transformation of ownership relations, privatization, and demarcation of land ownership. The problems of land relations in Russia were identified by studying such parameters as the structure of agricultural land ownership, agricultural land distribution by a form of management, and composition of agricultural land use by a form of ownership.

We summarized the major problems of contemporary land relations in Russia to be the lack of a clear land policy, insignificant changes to the structure of land distribution by a form of management, low share of owned land in the use of agricultural organizations, inadequate information on the quantity, structure, and dynamics of the land resources, low efficacy of land management system, and aggravation of land degradation processes. The prospective measures to improve the efficiency of land ownership and land use patterns could be built along the core, support, incentive, and protection blocks of the land management system to include the unification of the land policy doctrine, re-establishment of a single body for regulation of land relations and rational land use, carrying out a comprehensive inventory of agricultural land, establishment of an effective system to combat land degradation, anti-trust regulations to prevent concentration of land in mega-holdings, and information and consulting support for rational use and protection of agricultural land.

Land distribution, land ownership, and land use issues require comprehensive studies to critically evaluate and adjust the land management measures to territorial specifics of the land market in various parts of the country. To our mind, the future research directions in this area should include the elaboration of a thorough methodology for strategic forecasting and planning of land use and protection of land resources; establishment of a system of information support for land management; scientific justification and development of a set of measures for the development of the agricultural land market infrastructure; engineering of digital models of optimal distribution and use of land plots at federal, regional, and municipal levels; improvement of methods and technologies for the protection and reproduction of agricultural land; and development of technical solutions for monitoring of agricultural land based on remote sensing and GIS technologies.

\section{Conflict of interests}

The authors declare no conflict of interest. 


\section{References}

1. Bryzhko, V. (2013). Problems of Perfection of an Agricultural Land Use. In the World of Scientific Discoveries, 48(12), 221-238.

2. Cai, M., Murtazashvili, I., \& Murtazashvili, J. (2020). The Politics of Land Property Rights. Journal of Institutional Economics, 16(2), 151-167.

3. Constantin, M., Radulescu, I.D., Andrei, J.V., Chivu, L., Erokhin, V., \& Gao, T. (2021). A Perspective on Agricultural Labor Productivity and Greenhouse Gas Emissions in Context of the Common Agricultural Policy Exigencies. Economics of Agriculture, 68(1), 53-67.

4. Dugina, T. (2015). Problems of Development of Land Relations in Russian Agriculture. Concept, 21, 75330.

5. Erokhin, V., \& Gao, T. (Eds.). (2020). Handbook of Research on Globalized Agricultural Trade and New Challenges for Food Security. Hershey, PA: IGI Global.

6. Erokhin, V., Gao, T., Andrei, J.V., \& Ivolga, A. (2020a). Transformation of Agricultural Land Distribution Patterns in Russia. Economics of Agriculture, 67(3), 863-879.

7. Erokhin, V., Gao, T., \& Ivolga, A. (2020b). Structural Variations in the Composition of Land Funds at Regional Scales across Russia. Land, 9(6), 201. doi:10.3390/ land9060201.

8. Federal Service for State Registration, Cadastre, and Cartography. (2021). Availability and Allocation of Lands in the Russian Federation. Retrieved from https://rosreestr.ru/site/activity/sostoyame-zemerrossii/gosudarstvennyynatsionalnyy-doklad-o-sostoyanii-i-ispolzovanii-zemel-v-rossiyskoy-federatsii/ (May 24, 2021).

9. Gadzhiev, I. (2015). Problems of Development of Sustainable Land Management: Conservation and Sustainable Use of Agricultural Land. Fundamental Research, 10(3), 570-574.

10. Gao, T., Erokhin, V., \& Arskiy, A. (2019). Dynamic Optimization of Fuel and Logistics Costs as a Tool in Pursuing Economic Sustainability of a Farm. Sustainability, 11(19), 5463.

11. Gao, T., Ivolga, A., \& Erokhin, V. (2018). Sustainable Rural Development in Northern China: Caught in a Vice between Poverty, Urban Attractions, and Migration. Sustainability, 10(5), 1467.

12. Kalugina, Z. (2019). Land Relations in the Agrarian Sector of Russia. Ideas and Ideals, 11(2-2), 330-350.

13. Khlystun, V. (2018). The Important Investigations in the Field of Land Relations and Land Administration. Land Management, Monitoring and Cadastre, 163(8), 5-10. 
14. Khlystun, V. (2019). Development of Land Relations in the Agroindustrial Complex. Herald of the Russian Academy of Sciences, 89(4), 325-332.

15. Kim, Y. (2019). The Historical Limits of Capitalist Private Landed Property and Alternatives for Land Property Right. Journal of Korea Planning Association, 54(2), 141-159.

16. Kostyaev, A., Nikonova, G., \& Trafimov, A. (2015). Land Capacity of Rural Territories: Prospects of Development. Economics of Agriculture of Russia, 11, 2430.

17. Kotelevskaya, N. (2018). Land Relations - The Basis of Increasing the Efficiency of Land Resources in the Agriculture Industry. Region: Systems, Economy, Management, 42(3), 111-118.

18. Kuzmich, N., \& Gorr, E. (2016). Specificity of Land Relations in Agriculture. The Far East: Problems of Development of the Architectural and Building Complex, 1, 258-260.

19. Melnikov, N. (2019). A Multi-Contour Land Plot as an Object of Land Relations: Theory and Practice. Courier of Kutafin Moscow State Law University (MSAL), 53(1), 64-74.

20. Minakov, I. (2017). Agricultural Productive Cooperative Stores and Prospects of their Development in Russia. Technologies for the Food and Processing Industry of AIC - Healthy Food, 3, 105-113.

21. Mindrin, A., \& Leppke, O. (2008). Organization of Agricultural Land Use. AIC: Economy, Management, 5, 2-10.

22. Panait, M., Erokhin, V., Andrei, J.V., \& Gao, T. (2020). Implication of TNCs in Agri-Food Sector - Challenges, Constraints and Limits - Profit or CSR? Strategic Management, 20(4), 33-43.

23. Prabhakar, A.C., Kaur, G., \& Erokhin, V. (Eds.). (2020). Regional Trade and Development Strategies in the Era of Globalization. Hershey, PA: IGI Global.

24. Prishchepov, A., Müller, D., Dubinin, M., Baumann, M., \& Radeloff, V. (2013). Determinants of Agricultural Land Abandonment in Post-Soviet European Russia. Land Use Policy, 30, 873-884.

25. Saifidinov, B., \& Kostousova, A. (2019). Development of Land Relations in the Russian Federation in Modern Conditions. Tendencies of Development of Science and Education, 48(3), 63-67.

26. Sharipov, S., Yakushkin, N., \& Kharisov, G. (2018). Improvement of Land Relations as the Base of Economic Growth of Rural Territories and Business. Economy of Agricultural and Processing Enterprises, 7, 19-24.

27. Scott, M., Gallent, N., \& Gkartzios, M. (Eds.). (2019). The Routledge Companion to Rural Planning. London: Routledge.

28. Sergeeva, L. (2019). Transformation of Land Relations in the Agrarian Sector Regions. Bulletin NGIEI, 98(7), 118-127. 
29. Sikandar, F., Erokhin, V., Shu, W.H., Rehman, S., \& Ivolga, A. (2021). The Impact of Foreign Capital Inflows on Agriculture Development and Poverty Reduction: Panel Data Analysis for Developing Countries. Sustainability, 13(6), 3242.

30. Trafimov, A., \& Nikonov, A. (2018). Land Control in the System of Land Relations Regulation in the Agricultural Sector. Economy of New World, 11(3), 21-39.

31. Vishkaev, S., \& Musaev, M. (2019). Principles of Regulation of Land Relations. Education. Science. Academic Personnel, 2, 83-85.

32. Vlasov, V., Vorobeva, A., \& Nesmelova, E. (2019). Some Legal Contradictions in the Development of Land Relations in Agriculture of Russia. Era of Science, 18, $12-17$.

33. Volkov, S., Papaskiri, T., Alekseenko, N., Ananicheva, E., \& Rudinova, Y. (2020). Land-Property and Land-Resource Information Obtained as a Result of Land Management. IOP Conference Series: Earth and Environmental Science, 579, 012132.

34. Vorobyov, A., Fedyunina, E., \& Oganesian, L. (2019). Improvement of the Land Relations at the Regional Level Taking into Account the Retrospective Analysis of Land Transformations. Land Management, Monitoring and Cadastre, 68(1), 26-30.

35. Zavorotin, E., Gordopolova, A., \& Turina, N. (2019a). Institutions of Land Relations in Agriculture. Economics of Agriculture of Russia, 10, 9-14.

36. Zavorotin, E., Tyurina, N., \& Gordopolova, A. (2019b). Theoretical Aspects of Developing the Mechanism of Land Relations Transformation in Agriculture. Research Review: Theory and Practice, 63(7), 910-917.

37. Zharov, A. (2019). Land Policy and Land Relations in Russia: Past and Present. Bulletin of Moscow State Region University, 2, 52-65. 